\title{
ORIGINAL ARTICLE \\ Effect of Exposure to Electromagnetic Radiation on Sex Steroids and Systemic \& Local Uterine Redox Status during Early and Late Pregnancy in Rats
}

\author{
Akmal Ahmed Hassan Diab, Mohamed Hussein Mohamed Ibrahim,Shreen Elaraby Bedear, \\ Eman AbdelRaouf Mohammed \\ Medical physiology Department, Faculty of Medicine, Zagazig University, Zagazig, Egypt
}

\section{Corresponding author}

Eman Abdel Raouf Mohammed

Medical Physiology Department, Faculty of Medicine, Zagazig University.

eyym127@gmail.com

$\begin{array}{ll}\text { Submit Date } & 2019-04-21 \\ \text { Revise Date } & 2019-05-07 \\ \text { Accept Date } & 2019-05-17\end{array}$

\section{ABSTRACT}

Background: pregnant women are at high risk of exposure to environmental EMR because of their higher oxygen consumption and amniotic fluid-induced ROS, which is associated with adverse pregnancy outcomes. The present study was designed to demonstrate the effects of EMR exposure at 900, 1800, and 2450 $\mathrm{MHz}$ on the female sex hormones (estrogen, progesterone) and systemic and local uterine redox status during early and late stages of pregnancy in adult albino rats. Methods: The present study was carried out on 88 weaned albino female rats were divided into four equal groups: control group: rats were not exposed to EMR, group2: rats were exposed to $900 \mathrm{MHz}$ EMR, group3: rats were exposed to $1800 \mathrm{MHz}$ EMR (emitted from mobile phones), and group 4: rats were exposed to $2450 \mathrm{MHz}$ EMR (emitted from Wi-Fi). After induction of pregnancy each group was subdivided into two equal groups: early pregnant and late pregnant subgroups. At the end of each experimental period samples were collected for estimation of serum estradiol \& progesterone and plasma and local oxidative stress markers. Results: The present study showed that EMR exerted a significant frequency and duration dependent reduction in serum estrogen, progesterone, plasma TAS, vitamin C and uterine GSH which was accompanied by significant increase in plasma and uterine MDA. Conclusions: Exposure to EMR induced progressive reduction in sex steroid hormones, and imbalance in oxidative/antioxidative stress parameters in pregnant rats. These effects were dependent on the frequency and the duration of the EMR.

Key word: EMR; Oxidative stress; Pregnancy.

\section{INTRODUCTION}

$\mathrm{T}$ he wireless local area network (WLAN) systems, a substitute to wired internet access provides a mean of communication and information exchange; but it produces electromagnetic radiation (EMR) at a frequency of $2450 \mathrm{MHz}$.Also mobile phones produce EMR through their base station antennae in the frequency range of $900-1800 \mathrm{MHz}$ for the Global System for Mobile Communications [1].

The portable computers and mobile phones are commonly placed on the legs and in the pockets of humans, and thus expose the genital area to EMR [2].

Reactive Oxygen Species (ROS) production is associated with enhanced exposure to EMR [3] and together with free radicals affect the reproductive system in both humans and animals [4].

On the other hand, pregnant women are at specific risk of exposure to environmental EMR because of their higher oxygen consumption and amniotic fluid-induced ROS production [5].

There are some data about the effects of extremely low electrical field (ELF)-EMR (50 $\mathrm{Hz}$ ) on the female reproductive function [6].

So the aim of the present study is to investigate the effects of exposure to different waves of EMR (900, 1800 and $2450 \mathrm{MHz}$ ) on sex steroids and the systemic \& local uterine redox status during early and late pregnancy after 


\section{MATERIAL AND METHODS}

The study was approved by the research ethical committee of Faculty of Medicine, Zagazig University.

Experiments complied with the ARRIVE guidelines and was carried out in accordance with the National Institutes of Health guide for the care and use of Laboratory animals (NIH Publications No. 8023, revised 1978) .

The present study was carried on 99 weaned albino rats 88 female rats plus 11 male rats for fertilization weighing 35-50 gm (initial weight).

The animals were divided into male and female groups:

- Male group ( $\mathbf{n = 1 1})$ : used for induction of pregnancy that was carried out at the age of 8 weeks in both genders.

- Female groups $(\mathbf{n =}$ 88): Female rats were subdivided according to EMR exposure into 4 equal subgroups: Subgroup 1 (control), Subgroup 2 (900MHz), Subgroup 3 (1800MHz) and Subgroup 4 (2450MHz).

Female rats in control subgroup were not exposed to EMR and after induction of pregnancy; it further subdivided into 2 equal subgroups early (1a) at $7^{\text {th }}$ and late (1b) at $18^{\text {th }}$ days of gestation.

Female rats in subgroups 2, 3 and 4 were exposed to different frequencies of EMR every day from age of 3 weeks and after induction of pregnancy; each subgroup further subdivided into 2 equal subgroups: early pregnant subgroups were exposed until $7^{\text {th }}$ day of gestation (2a, 3a and 4a) and late pregnant subgroups were exposed until $18^{\text {th }}$ day of gestation (2b, $3 b$ and $4 b)$.

At the previous selected days of pregnancies all pregnant subgroups were sacrificed and blood samples were collected for measurement of serum estradiol \& progesterone and measurement of plasma oxidative stress markers (lipid peroxidation, total antioxidant status (TAS) and vitamin C).

Uterine tissue samples were collected for measurement of local uterine oxidative stress markers (lipid peroxidation and reduced glutathione).

\section{Induction of pregnancy:}

Vaginal smears taken from the female rats were examined daily by using light microscope to ensure that they were in regular estrus cycle The estrus phase of the estrus cycle was detected by the presence of cornified epithelial cells which increase in number and eventually predominate as the estrus progressed [7]. The female proved to be in estrus phase was paired with a mature male rat in a separate cage for 24 hours. After mating, females were subsequently isolated until the time of analysis to ensure accurate gestation timing, and in the next morning a vaginal smear taken. Copulation was confirmed by the presence of a copulation plug or spermatozoa in the vagina. The presence of sperms or vaginal plug was designated gestational day zero [8].

\section{Sampling of blood:}

Blood samples were collected from the retro orbital plexus of each rat under ether anesthesia using glass capillaries. The collected blood used for analysis of plasma MDA, TAS and vitamin $\mathrm{C}$. It is also used for analysis of serum estradiol and progesterone.

\section{Preparation of uterine tissue samples:}

The rats were sacrificed on $7^{\text {th }}$ and $18^{\text {th }}$ days of gestation in each group by decapitation. The abdomen was opened, the uterine horns were dissected, and then the pregnant uteri were cleaned from fat, placenta, fetus, fetal membrane and then rinsed thoroughly with cold saline solution and after processing used for assaying MDA and GSH.

\section{Assessment of lipid peroxidation:}

Lipid peroxidation levels in the uterine homogenate and plasma samples were measured by assaying for thiobarbituric acidreactive substances [9].

\section{TAS analysis:}

The plasma TAS level was measured using Colorimetric Assay kits. The results in the plasma were expressed in $1 \mathrm{~mol} \mathrm{H}_{2} \mathrm{O}_{2}$ equivalent/liter $\left(1 \mathrm{~mol} \mathrm{H}_{2} \mathrm{O}_{2}\right.$ equiv/l).

Measurement of plasma vitamin $C$ : 
Quantification of ascorbic acid in the plasma samples was performed according to the method of Rutkowski and Grzegorczyk [10] the absorbance of the samples was measured spectrophotometrically at $700 \mathrm{~nm}$.

\section{Measurement of reduced glutathione:}

The GSH content of the uterine samples was measured at $412 \mathrm{~nm}$ using Ellman's reagent [11].

Estimation of serum Estradiol (E2) level: using rat ELISA Kits.

Estimation of serum Progesterone level: using rat ELISA Kits.

\section{Statistical analysis:}

SPSS version 18.0 program for Windows (SPSS Inc. Chicago, IL, USA) was used.

\section{RESULTS}

It was found that all studied frequencies of EMR (900, 1800 and $2450 \mathrm{MHz}$ ) had significantly decreased serum E2 and progesterone in early and late pregnant rats $(p<0.001)$ when compared to control groups (Tables 1 and 2) (Figure1).

Moreover, exposure to EMR with frequency of $2450 \mathrm{MHz}$ significantly decreased serum E2 in early $(\mathrm{p}<0.05)$ and late $(\mathrm{p}<0.001)$ pregnant rats when compared to early and late pregnant rats exposed to EMR with frequency of $900 \mathrm{MHz}$ in addition, serum E2 was significantly decreased in late pregnant rats exposed to $2450 \mathrm{MHz}$ (group 4b) when compared to rats exposed to $1800 \mathrm{MHz}$ (group $3 b)$ frequency radiation $(\mathrm{p}<0.01)$. However, there was an insignificant change in serum E2 among early and late pregnant groups exposed to radiation with frequency of 900 and 1800 MHz ( $>$ >0.05) (Tables 1 and 2).

Regarding serum progesterone, it showed significant reduction in both early and late pregnant exposed to EMR with frequency of $1800 \mathrm{MHz}(\mathrm{p}<0.01$, and 0.05; respectively) and $2450 \mathrm{MHz}$ ( $<<0.001$ in both groups) when compared to groups exposed to $900 \mathrm{MHz}$, which was also significantly decreased in groups exposed to $2450 \mathrm{MHz}$ ( $\mathrm{p}<0.05$, and 0.01 ; respectively) when compared to groups exposed to $1800 \mathrm{MHz}$ (Tables 1 and 2) (Figure1).

Moreover, our results showed significant progressive increase in serum MDA with increase the frequency of the EMR in early and late pregnant rats. It was significantly high in early pregnant animals in comparison to control ( $p<0.05,0.001$ and 0.001; respectively). Moreover, in late pregnant it showed significant increase in all exposure groups in comparison to control group $(\mathrm{P}<0.001,0.05,0.001$; respectively) (Tables 1 and 2) (Figure2).

In addition, its level showed significant increase in early and late exposed to $1800 \mathrm{MHz}$ frequency ( $\mathrm{p}<0.05$; in both groups) when compared to groups exposed to $900 \mathrm{MHz}$. Furthermore, rats exposed to $2450 \mathrm{MHz}$ showed significant increase in its level in comparison to those exposed to $900 \mathrm{MHz}$ ( $<<0.001$; in early and late pregnancy groups) and $1800 \mathrm{MHz} \quad(\mathrm{p}<0.001$; in early and late pregnancy groups) (Tables 1 and 2).

As regard to uterine MDA, it showed significant increase in early and late exposure groups exposed to $900 \mathrm{MHz}(\mathrm{p}<0.05 ; 0.05$ respectively), $1800 \mathrm{MHz} \quad(\mathrm{p}<0.05 ; 0.01$ respectively) and $2450 \mathrm{MHz}(\mathrm{p}<0.01,0.001$; respectively) when compared to control group.

In addition, exposure to $1800 \mathrm{MHz}$ in late pregnant rats significantly increased uterine MDA $(p<0.05)$ in comparison to group $2 b$ (table 2), with insignificant change between both groups in early pregnant rats $(p>0.05)$ (table 1).

Moreover, early and late exposure to 2450 $\mathrm{MHz}$ showed significant increase in its level in comparison to those exposed to $900 \mathrm{MHz}$ $(\mathrm{p}<0.05,0.01$; respectively) and $1800 \mathrm{MHZ}$ ( $<<0.05$; in early and late pregnancy groups)

(Tables 1 and 2).

However, a non-significant difference in the uterine GHS level in early pregnant rats exposed to $900 \mathrm{MHz}$ radiation in comparison to control group ( $>>0.05)$. In contrast, late pregnant rats exposed to $900 \mathrm{MHz}$ radiation showed significant increase in uterine GSH level in comparison to control group $(\mathrm{p}<0.05)$. 
However, there was an insignificant difference in uterine GSH levels among groups exposed to $900 \mathrm{MHz}$ and $1800 \mathrm{MHz}$ radiation.

Moreover, its level showed significant increase in early and late exposed to $1800 \mathrm{MHz}$ frequency $(\mathrm{p}<0.05 ; 0.01$; respectively) when compared to control group. Furthermore, rats exposed to $2450 \mathrm{MHz}$ showed significant increase in its level in comparison to control group $(\mathrm{P}<0.001$; in early and late pregnancy groups), those exposed to $900 \mathrm{MHz}$ ( $\mathrm{p}<0.001$; in early and late pregnancy groups) and those exposed to $1800 \mathrm{MHz}$ ( $\mathrm{p}<0.05$; in early and late pregnancy groups) (Tables 1 and 2).

In respect to the antioxidant markers, plasma TAS showed significant decrease in all exposure groups with $\mathrm{p}<0.05$ in early and late pregnant rats exposed to $900 \mathrm{MHz}$ radiation, $\mathrm{p}<$ 0.05 and $p<0.01$ in early and late pregnant rats exposed to $1800 \mathrm{MHz}$ radiation; respectively, and $\mathrm{p}<0.01$ and $\mathrm{p}<0.001$ in early and late pregnant rats exposed to $2450 \mathrm{MHz}$ radiation; respectively when compared to control group. (Figure3)

Moreover, early and late exposure to EMR with $1800 \mathrm{MHz}$ frequency significantly reduced plasma TAS when compared to groups exposed to $900 \mathrm{MHz}$ ( $\mathrm{p}<0.05,0.01$; respectively). Further, early and late exposure to EMR with $2450 \mathrm{MHz}$ frequency significantly reduced plasma TAS when compared to groups exposed to $900 \mathrm{MHz}$ ( $\mathrm{p}<0.01,0.05$; respectively), and in comparison to groups exposed to $1800 \mathrm{MHz}$ ( $\mathrm{p}<0.01)$ (Tables 1 and 2) (Figure3).

Interestingly, plasma vitamin $\mathrm{C}$ level showed a significant reduction in early and late groups exposed to $1800 \mathrm{MHz}(\mathrm{p}<0.05,0.01$; respectively) and $2450 \mathrm{MHz}$ radiation $(\mathrm{p}<0.01$, 0.001 ; respectively) in comparison to control group.in addition a significant decrease in its level was found in late pregnant rats exposed to $900 \mathrm{MHz}(\mathrm{p}<0.05)$ when compared to control group. However, no significant difference was found between group $2 \mathrm{a}$ and control group ( $p>0.05)$ (Figure4)

Moreover, early and late exposure to $2450 \mathrm{MHz}$ significantly reduced vitamin $\mathrm{C}$ level in comparison to rats exposed to $900 \mathrm{MHz}(\mathrm{p}<; 0.5$, 0.01 ; respectively). Furthermore, late exposure to $2450 \mathrm{MHz}$ significantly reduced vitamin C level in comparison to rats exposed $1800 \mathrm{MHz}$ $(\mathrm{p}<0.05)$. In contrast, there was non-significant change in vitamin $\mathrm{C}$ level between both groups in early pregnant rats $(\mathrm{p}>0.05)$ (Figure4).

Table 1. Effect of EMR on all studied parameters in the early pregnant studied subgroups

\begin{tabular}{|c|c|c|c|c|}
\hline $\begin{array}{ll}\text { Parameters } & \text { Groups }(\mathrm{n}=11)\end{array}$ & $\begin{array}{l}\text { Group 1a } \\
\text { (Control) }\end{array}$ & $\begin{array}{l}\text { Group 2a } \\
(900 \mathrm{MHz})\end{array}$ & $\begin{array}{l}\text { Group 3a } \\
(1800 \mathrm{MHz})\end{array}$ & $\begin{array}{l}\text { Group 4a } \\
(2450 \mathrm{MHz})\end{array}$ \\
\hline serum estradiol (pg /ml) & $54.76 \pm 5.01$ & $47.40 \pm 6.20^{\mathrm{a}^{*}}$ & $45.66 \pm 2.94^{\mathrm{a}^{*}}$ & $42.65 \pm 2.77^{\mathrm{a}^{*} \mathrm{~b} \#}$ \\
\hline $\begin{array}{l}\text { serum progesterone } \\
(\mathrm{pg} / \mathrm{ml})\end{array}$ & $36.94 \pm 3.79$ & $29.72 \pm 2.54^{\mathrm{a}^{*}}$ & $25.46 \pm 2.62^{\mathrm{a} * \mathrm{~b} \$}$ & $22.72 \pm 2.41^{\mathrm{a} \mathrm{a}^{*} \mathrm{c} \#}$ \\
\hline Plasma MDA (nmol/L) & $112.57 \pm 6.04$ & $121.77 \pm 4.31^{\mathrm{a} \#}$ & $131.71 \pm 9.06^{\mathrm{a} * \mathrm{~b} \#}$ & $168.17 \pm 8.41^{\mathrm{a} * \mathrm{~b} * \mathrm{c}^{*}}$ \\
\hline $\begin{array}{c}\text { Plasma TAS }\left(\mu \mathrm{mol} \mathrm{H}_{2} \mathrm{O}_{2}\right. \\
\text { equiv. } / \mathrm{L})\end{array}$ & $2.49 \pm 0.11$ & $2.29 \pm 0.12^{\mathrm{a} \#}$ & $2.15 \pm 0.09^{\mathrm{a} \# \mathrm{~b} \#}$ & $1.74 \pm 0.14^{\mathrm{a} \$ \mathrm{~b} \$ c \$}$ \\
\hline Plasma vitamin $C(\mu \mathrm{mol} / \mathrm{L})$ & $40.36 \pm 5.38$ & $38.32 \pm 4.69$ & $35.34 \pm 5.54^{\mathrm{a} \#}$ & $32.97 \pm 5.69^{\mathrm{aSb} \#}$ \\
\hline $\begin{array}{c}\text { Uterine MDA (nmol/gm } \\
\text { tissue) }\end{array}$ & $6.86 \pm 0.37$ & $7.42 \pm 0.67^{\mathrm{a} \#}$ & $7.68 \pm 0.74^{\mathrm{a} \#}$ & $8.25 \pm 0.65^{\text {a\$b\#c\# }}$ \\
\hline $\begin{array}{c}\text { Uterine GSH }(\mu \mathrm{mol} / \mathrm{gm} \\
\text { tissue })\end{array}$ & $28.62 \pm 3.21$ & $26.56 \pm 2.47$ & $25.70 \pm 2.66^{\mathrm{a} \#}$ & $23.01 \pm 3.19^{\mathrm{a} * \mathrm{~b} \$ \mathrm{c} \#}$ \\
\hline
\end{tabular}

Values are means \pm SD

a: sig vs control group; b: sig vs group2a; c: sig vs group $3 \mathrm{a} ;{ }^{*}: \mathrm{p}<0.001 ; \$: \mathrm{p}<0.01 ; \# \mathrm{p}<0.05$ 
Table 2. Effect of EMR on all studied parameters in the late pregnant studied subgroups

\begin{tabular}{|c|c|c|c|c|}
\hline $\begin{array}{l}\text { Groups }(\mathbf{n}=11) \\
\text { Parameters }\end{array}$ & $\begin{array}{l}\text { Group 1b } \\
\text { (Control) }\end{array}$ & $\begin{array}{l}\text { Group 2b } \\
(900 \mathrm{MHz})\end{array}$ & $\begin{array}{l}\text { Group 3b } \\
(1800 \mathrm{MHz})\end{array}$ & $\begin{array}{l}\text { Group 4b } \\
(2450 \mathrm{MHz})\end{array}$ \\
\hline $\begin{array}{l}\text { Serum estradiol } \\
(\mathrm{pg} / \mathrm{ml})\end{array}$ & $91.82 \pm 7.02$ & $72.59 \pm 6.43^{\mathrm{a}^{*}}$ & $71.15 \pm 6.92^{\mathrm{a}^{*}}$ & $61.62 \pm 4.94^{\mathrm{a} * \mathrm{~b} * \mathrm{c} \$}$ \\
\hline $\begin{array}{l}\text { Serum progesterone } \\
(\mathrm{pg} / \mathrm{ml})\end{array}$ & $33.24 \pm 3.09$ & $27.87 \pm 2.62^{\mathrm{a}^{*}}$ & $25.24 \pm 2.80^{\mathrm{a} * \mathrm{~b} \#}$ & $20.92 \pm 3.22^{\mathrm{a} * \mathrm{~b} * \mathrm{c} \$}$ \\
\hline Plasma MDA (nmol/L) & $113.02 \pm 6.43$ & $127.76 \pm 9.08^{\mathrm{a}^{*}}$ & $137.38 \pm 11.42^{\mathrm{a} * \mathrm{~b} \#}$ & $185.04 \pm 7.14^{\mathrm{a}^{*} \mathrm{~b} * \mathrm{c}^{*}}$ \\
\hline $\begin{array}{c}\text { Plasma TAS }\left(\mu \mathrm{mol} \mathrm{H}_{2} \mathrm{O}_{2}\right. \\
\text { equiv. } / \mathrm{L})\end{array}$ & $2.53 \pm 0.15$ & $2.22 \pm 0.11^{\mathrm{a} \#}$ & $2.08 \pm 0.14^{\mathrm{a} \$ \mathrm{~b} \$}$ & $1.63 \pm 0.22^{\mathrm{a}^{*} \mathrm{~b} \# \mathrm{c} \$}$ \\
\hline $\begin{array}{c}\text { Plasma vitamin } C \\
(\mu \mathrm{mol} / \mathrm{L})\end{array}$ & $39.96 \pm 3.36$ & $35.77 \pm 4.90^{\text {a\# }}$ & $33.78 \pm 6.23^{\mathrm{a} \$}$ & $28.64 \pm 4.43^{\mathrm{a} * \mathrm{~b} \$ \mathrm{c} \#}$ \\
\hline $\begin{array}{c}\text { Uterine MDA (nmol/gm } \\
\text { tissue) }\end{array}$ & $6.89 \pm 0.49$ & $7.59 \pm 0.48^{\mathrm{a} \#}$ & $8.18 \pm 0.61^{\mathrm{a} \$ \mathrm{~b} \#}$ & $9.20 \pm 0.82^{\mathrm{a}^{*} \mathrm{~b} \$ \mathrm{c} \#}$ \\
\hline $\begin{array}{c}\text { Uterine GSH }(\mu \mathrm{mol} / \mathrm{gm} \\
\text { tissue) }\end{array}$ & $29.18 \pm 4.61$ & $24.98 \pm 3.03^{\mathrm{a} \#}$ & $23.67 \pm 3.61^{\mathrm{as}}$ & $20.28 \pm 3.52^{\mathrm{a} * \mathrm{~b} \$ \mathrm{c} \#}$ \\
\hline
\end{tabular}

Values are means \pm SD

a: sig vs control group; $b$ : sig vs group $2 b ; c$ : sig vs group $3 b *$ : $p<0.001, \$: p<0.01 ; \#: p<0.05$

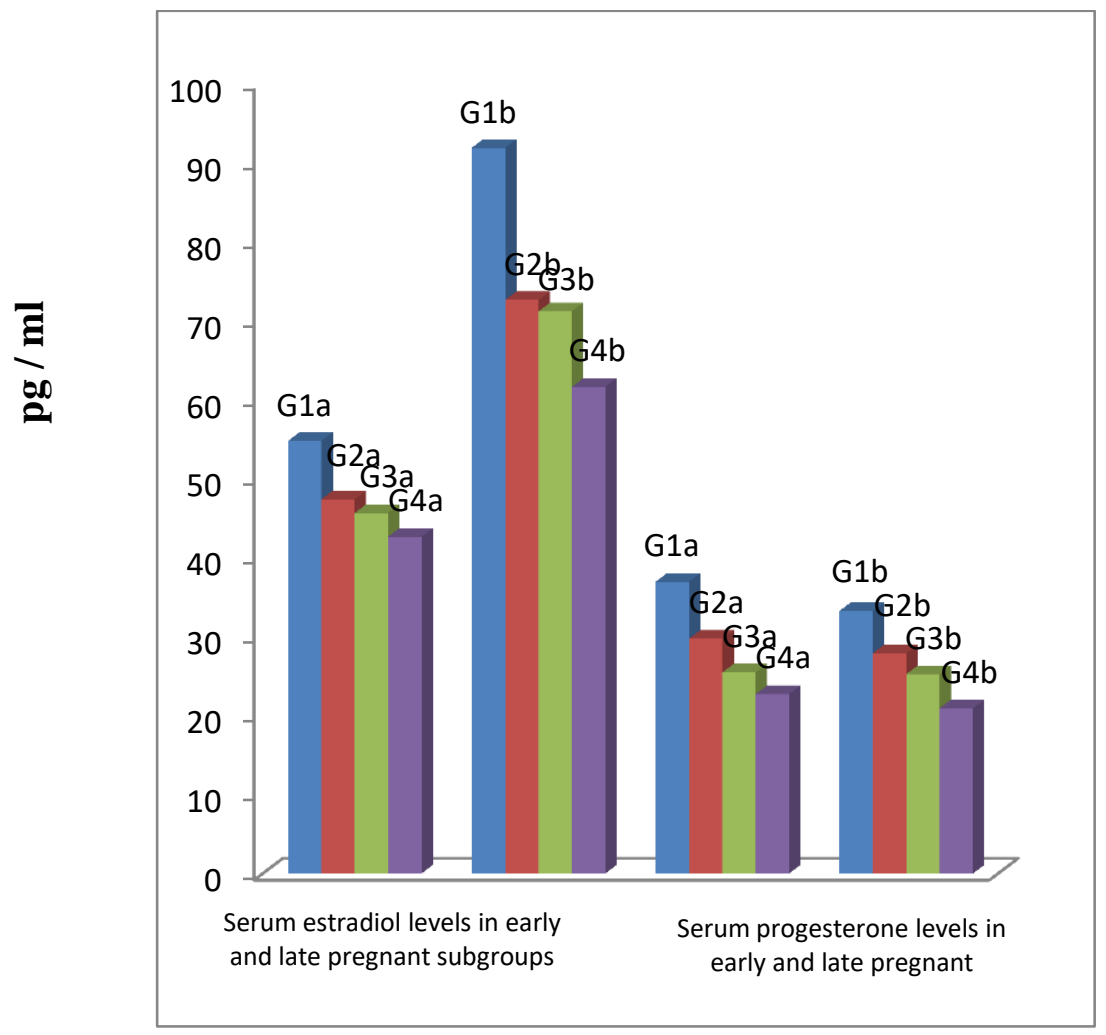

Figure 1. Serum estradiol and progesterone levels in early and late pregnant subgroups 


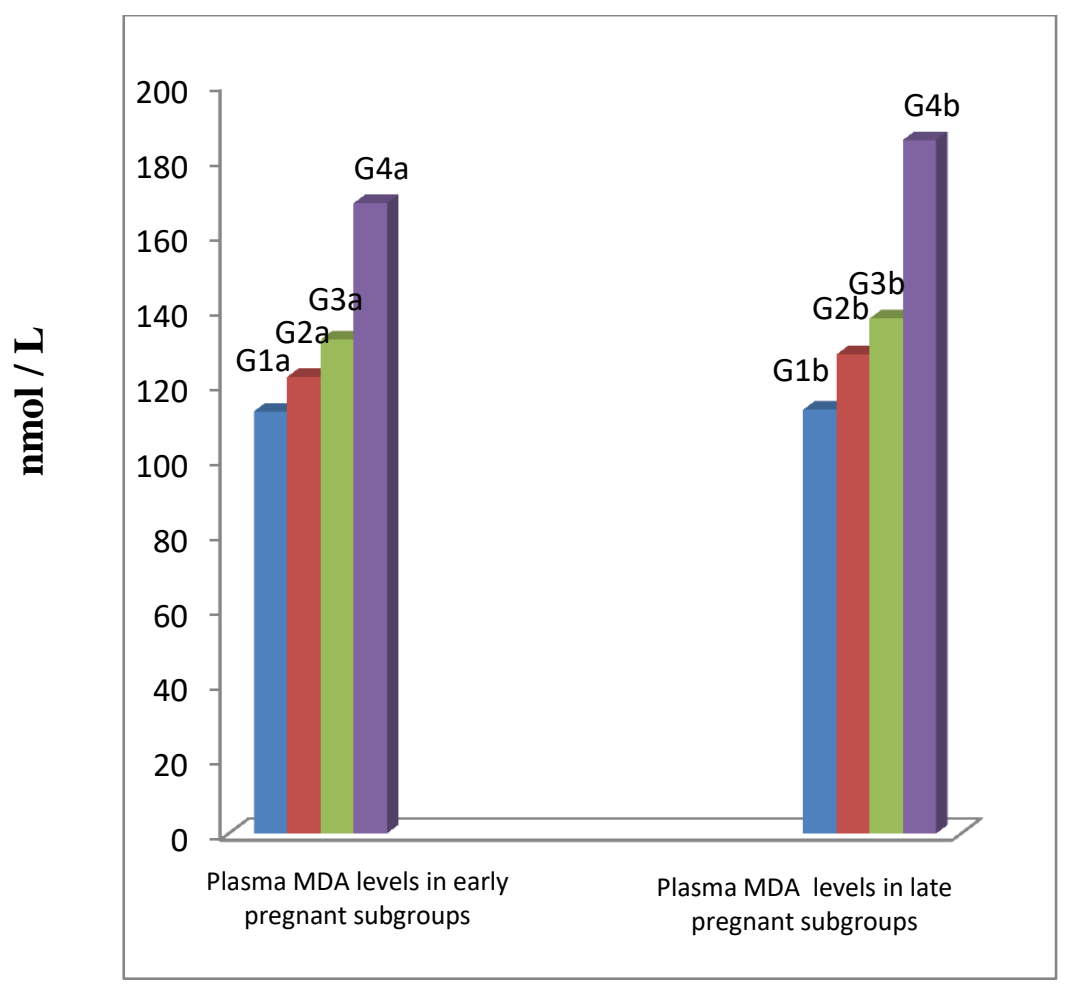

Figure 2. Plasma MDA levels in early and late pregnant subgroups

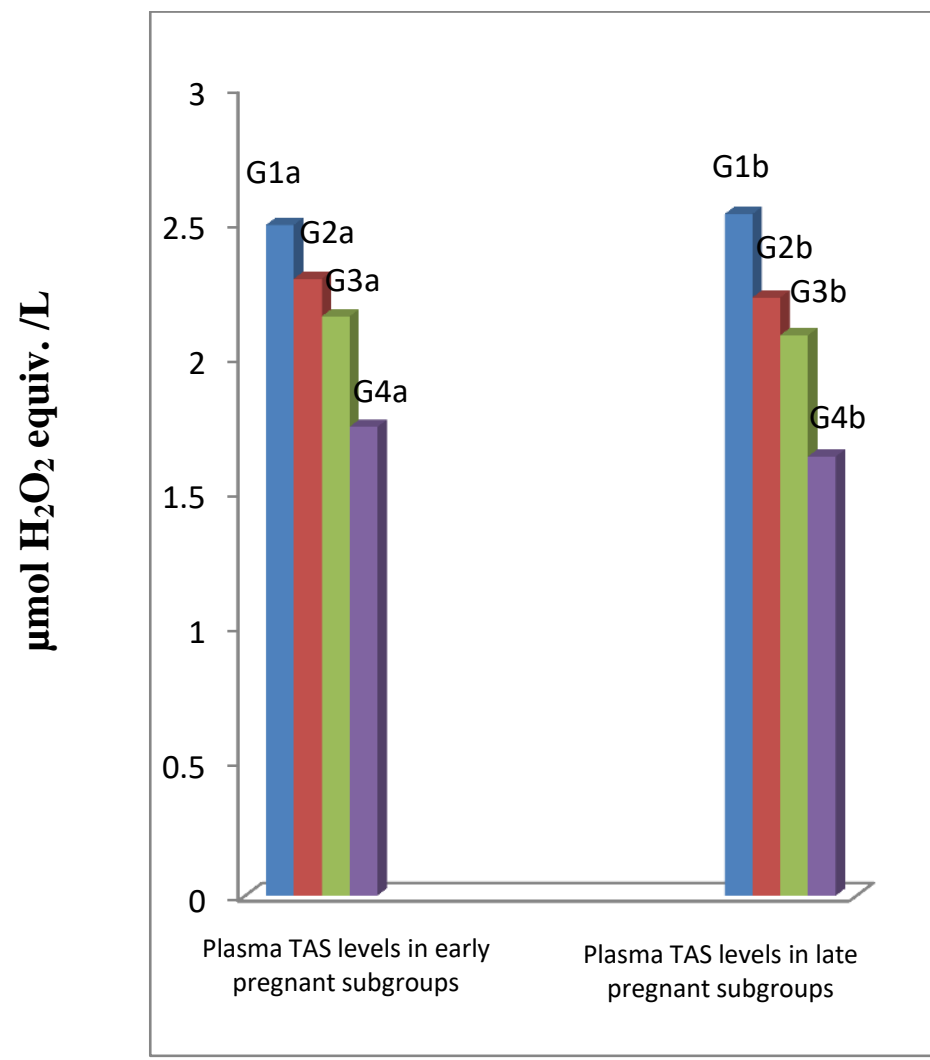

Figure 3. Plasma TAS levels in early and late pregnant subgroups 


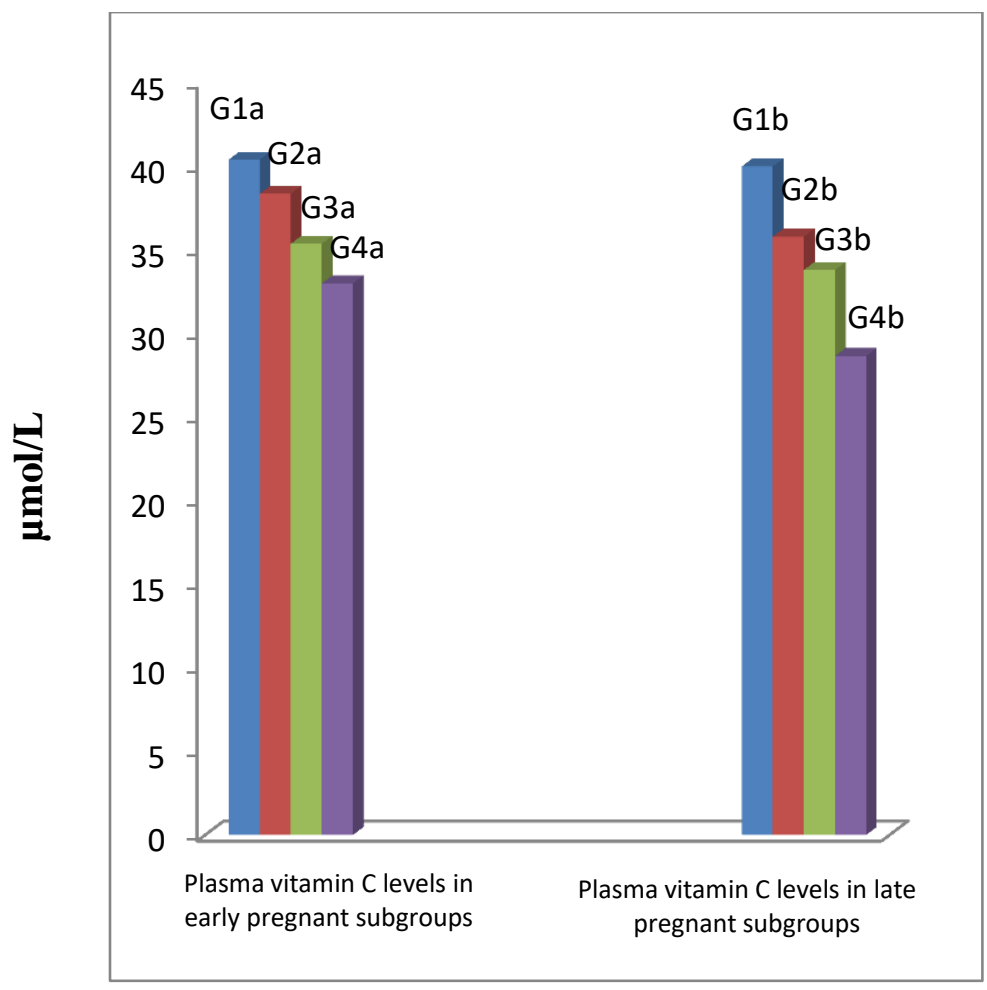

Figure 4. Plasma vitamin C levels in early and late pregnant subgroups

\section{DISCUSSION}

There is growing interest in the increase risk of EMR-induced environmental pollution. EMR exposure modifies cellular antioxidant levels as well as hormonal homeostasis in humans and animals. Although the pathophysiologic mechanisms that are responsible for such effects remain unknown, common theories include changes in temperature, membrane permeability, and ROS production may be implicated [12].

The current reports about the effect of EMR exposure on female reproductive tract in human [1] and animals [13] are conflicting. Although in most cases, exposure to EMR increases ROS levels in human, mouse and rat cells, there are also studies showing that ROS levels were decreased or not affected by EMR. Multiple factors could cause these discrepancies, including EMR type, intensity, frequency and exposure time [14].

The results of the current study showed significant increases in the systemic and local lipid peroxidation levels (MDA) associated with significant decreases in systemic (TAS and vitamin C) and local (GSH) antioxidant markers in both early and late pregnant subgroups after exposure to EMR at different frequencies $(900,1800$, and $2450 \mathrm{MHz})$ compared to the control subgroups.

Oxidative stress implicates in the etiopathogenesis of local female reproductive diseases such as endometriosis, polycystic ovarian disease, hydatidiform mole, and unexplained infertility). Also, there is growing evidence on its involvement in the pathophysiology of pre-eclampsia, free induced birth defects and other situations such as abortions [4]. In addition, oxidative stress may induce luteal regression and insufficient luteal hormonal support for the continuation of a pregnancy [15].

This present results are in agreement with several studies which reported changes in redox status in the different tissues after exposure to different frequencies of EMR. As, Türedi et al., [16] who observed that continuous exposure to 900-MHz of EMR for $1 \mathrm{~h} /$ day on postnatal 
days 22-59, caused an increase in oxidative stress and various pathological changes in bladders and kidneys of male rats. Also, Bodera et al., [17] revealed that exposure to $1800 \mathrm{MHz}$ of EMR caused elevation of MDA levels in blood, brain, and kidney of the experimental rats.

Furthermore, other studies detected marked increases in the inflammatory oxidative stress markers after exposure to EMR at $2450 \mathrm{MHz}$ exposures on different organs and tissues like heart [18], laryngeotracheal mucosal tissues [19], liver and kidney [20] by increasing MDA, total oxidant status, GSH-PX levels and decreasing TAS levels.

Moreover in concordance to the current data, Aksen et al., [21] stated that prolonged exposure to $50 \mathrm{~Hz}$ induced increasing in MDA levels in rat uterus and ovaries. Also Yuksel et al., [22] and Shahin et al. [23] who demonstrated that mobile phones emitting 900 and $1800 \mathrm{MHz}$ and Wi-Fi emitting $2450 \mathrm{MHz}$ EMR induced modification in the concentrations of local uterine oxidative stress markers of growing and maternal rats associated with drop in the plasma concentration of vitamin $\mathrm{C}, \mathrm{E}$ and $\mathrm{A}$.

On the other hand, in contrast to the present results Kismali et al., [13] detected nonsignificant difference of oxidative stress markers in the blood of pregnant rabbits after EMR exposure. The differences between the pervious study and the present study may be due to differences in: 1) species; rabbit versus rats, 2) duration of exposure; 7days versus 6 to 7 weeks, 3) frequencies of EMR; $1800 \mathrm{MHz}$ versus 900, 1800 and $2450 \mathrm{MHz}$ respectively. In addition the current results showed significant decreases in the serum estradiol and progesterone levels of both early and late pregnant subgroups after chronic exposure to EMR (900, 1800 and $2450 \mathrm{MHz}$ ) when compared with the control subgroups.

These results are in agreement with Ozguner et al., [24] who demonstrated that exposure to EMR at $900 \mathrm{MHz}$ declines plasma FSH \&LH levels in rats. Moreover, Shi et al., [25] and Al-
Akhras [26] reported that the levels of FSH, LH, estrogen and progesterone were significantly decreased after exposure of the gravid and non-gravid rats to ELF of $50 \mathrm{~Hz}$ EMR.

Furthermore these findings are confirmed by the results obtained from Yuksel et al., [22] and Shahin et al. [23] who detected that exposure to 900,1800 and $2450 \mathrm{MHz}$ EMR causes decrease in FSH, LH, estrogen, progesterone and prolactin levels in maternal and growing rats.

In contradiction to the above results, it was reported that the plasma progesterone and estrogen levels in rats were not changed by ELF $(50 \mathrm{~Hz})$ induced EMR exposure [27]. The discrepancies between the present finding and the latter study may be explained by difference in frequency of EMR 900, 1800 and $2450 \mathrm{MHz}$ versus $50 \mathrm{~Hz}$ respectively.

So, the significant shift of the systemic and local redox balance to the oxidative side in the early and late pregnancies after chronic exposure to different EMR frequencies (900, 1800 and $2450 \mathrm{MHz}$ ), starting before and during gestation in the present study pointed to the direct injurious effects of emitted mobile and Wi Fi EMR waves on the uterus. Further investigations are needed in humans, especially on young teenagers who often use their mobile phones for several hours per day.

\section{Declaration of interest}

The authors report no conflicts of interest. The authors alone are responsible for the content and writing of the paper.

Funding information: None declared

\section{REFERENCES}

1) Nazıroğlu M, Yükselm M, Kösem SA, Özkaya, M.O. Recent reports of Wi-Fi and mobile phone-induced radiation on oxidative stress and reproductive signaling pathways in females and males. J Membr Biol 2013; 246: 869-75.

2) International Commission on Non-Ionizing Radiation Protection (ICNIRP) SCI Review mobile phones, brain tumors and the interphone study: where are we now? Environ Health Perspect 2011; 119: 1534-38.

3) Kıvrak EG, Yurt KK, Kaplan AA, Alkan I, Altun 
G. $\quad$ Effects of electromagnetic

fields exposure on

the antioxidant defense system. J Microsc Ultrastruct 2017; 5(4): 167-76.

4) Agarwal A, Aponte-Mellado A, Premkumar BJ, Shaman A, Gupta S. The effects of oxidative stress on female reproduction: a review. Reprod Biol Endocrinol2012; 10: 49.

5) Calou CP, De Oliveira MF, Carvalho FC, Soares PR., Bezerra RA, De Lima SK et al.,: Maternal predictors related to quality of life in pregnant women in the Northeast of Brazil. Health Qual Life Outcomes 2018; 16(1): 109.

6) Kurokawa Y, Nitta H, Kabuto IM.: Acute exposure to $50 \mathrm{~Hz}$ magnetic fields with harmonic and transient components: lack of effects on night time hormonal secretion in men. Bio Electro Magnetics 2003; 24: 12-20.

7) Marcondes FK, Bianchi FJ, Tanno AP.): Determination of the estrous cycle phases of rats: some helpful considerations. Braz $\mathrm{J}$ Bio 2002; 62(4A):609-614.

8) Klukovits A, Gáspár R, Sánth P, Jancsó G, FalkaG. Functional and histochemical characterization of a uterine adrenergic denervation process in pregnant rats. Biol Reprod 2002; 67(3):1013-7.

9) Placer ZA, Cushman L, Johnson BC. Estimation of products of lipid peroxidation (malonyldialdehyde) in biological fluids. Anal Biochem1966; 16: 359-64.

10) Rutkowski M, Grzegorczyk K. Modifications of spectrophotometric methods for antioxidative vitamins determination convenient in analytic practice. Act Sci Pol Technol Aliment 2007; 6(3): 17-28.

11) Sedlak J, LindsayR.H.C. Estimation of total, protein bound and non-protein sulfhydryl groups in tissue with Ellmann's reagent. Anal Biochem 1968; 25:192-205.

12) Pall M. Wi-Fi is an important threat to human health. Environmental Research 2018; 164: 405-16.

13) Kismali G, Ozgur E, Guler G, Akcay A, Sel T, Seyhan N. The influence of $1800 \mathrm{MHz}$ GSMlike signals on blood chemistry and oxidative stress in non-pregnant and pregnant rabbits. Int J Rad Biol 2012; 88: 414-19.

14) Wang H, ZhangX. Magnetic fields and reactive oxygen species. Int JMol Sci 2017; 18 (10): E2175

15) Agarwal A, Allamaneni SS. Role of free radicals in female reproductive diseases and assisted reproduction. Reprod Biomed Online 2004; 9: 338-47.

16) Turedi S, Kerimoglu G, Mercantepe T, Odaci E. Biochemical and pathological changes in the male rat kidney and bladder following exposure to continuous $900-\mathrm{MHz}$ electromagnetic field on postnatal days 22-59. Int J Radiat Biol 2017; 1-10.

17) Bodera P, Stankiewicz W, Antkowiak B, Paluch $\mathrm{M}$, Kieliszek J, Sobiech J, et al.: Influence of electromagnetic field $(1800 \mathrm{MHz})$ on lipid peroxidation in brain, blood, liver and kidney in rats. Int JOccup Med Environ Health 2015; 28(4):751-9.

18) Saygin M, Gumral N, Asci H, Uguz AC, Celik O, Doguc DK, et al. The effects of electromagnetic radiation $(2450 \mathrm{MHz}$ wireless devices) on the heart and blood tissue: role of melatonin. Bratisl Lek Listy 2016; 117(11):665-71.

19) Aynali G, Nazıroğlu M, Çelik Ö, DoğanM, Yarıktaş M, Yasan H. Modulation of wireless $(2.45 \mathrm{GHz})$-induced oxidative toxicity in laryngotracheal mucosa of rat by melatonin. Eur Arch Otorhinolaryngol 2013; 270:1695700.

20) Salah MB, Abdelmelek $H$, Abderraba $M$. Effects of olive leave extract on metabolic disorders and oxidative stress induced by 2.45 $\mathrm{GHz}$ WIFI signals. Environ Toxicol Pharmacol 2013; 36(3):826-34.

21) Aksen F, Akdag MZ, Ketani A, Yokus B, Kaya A, Dasdag S. Effect of 50-Hz 1-mT magnetic field on the uterus and ovaries of rats (electron microscopy evaluation). Med Sci Monit 2006 ;12(6): 215-20

22) Yuksel M, Naziroglu M, Ozka MO. Long-term exposure to electromagnetic radiation from mobile phones and Wi-Fi devices decreases plasma prolactin progesterone, and estrogen levels but increases uterine oxidative stress in pregnant rats and their offspring. Endocrine 2016; 52: 352-62.

23) Shahin S, Singh SP, Chaturvedi CM. Mobile phone $(1800 \mathrm{MHz})$ radiation impairs female reproduction in mice, Mus musculus, through stress induced inhibition of ovarian and uterine activity. Reprd Toxicol 2017; 73: 41-60.

24) Ozguner M, Koyu A, Cesur G, Ural M, Ozguner F, Gokcimen A, et al. Biological and morphological effects on the reproductive 
organ of rats after exposure to electromagnetic field. Saudi Med J2005; 26(3): 405-10.

25) Shi Y, Bao X, Huo X, Shen Z, Song T. 50-Hz magnetic field (0.1-mT) alters c-fos mRNA expression of early post implantation mouse embryos and serum estradiol levels of gravid mice. Birth Defects Res B Dev Reprod Toxicol 2005; 74: 196-200.

26) Al-Akhras M.A. Influence of $50 \mathrm{~Hz}$ magnetic field on sex hormones and body, uterine, and ovarian weights of adult female rats. Electromagn Biol Med 2008; 27:155-163.

27) Aydin M, Cevik A, Kandemir FM, Yuksel M, Apaydin AM. Evaluation of hormonal change, biochemical parameters, and histopathological status of uterus in rats exposed to $50-\mathrm{Hz}$ electromagnetic field. Toxicol Ind Health 2009; 25(3):153-8.

To Cite This Article: Akmal AH, Mohamed HM,Shreen EB Eman AM, Effect of Exposure to Electromagnetic Radiation on Sex Steroids and Systemic \& Local Uterine Redox Status during Early and Late Pregnancy in Rats.ZUMJ 2020;26(1);186-195.DOi: 10.21608/zumj.2019.12044.1206 